\title{
PENEGAKAN HUKUM TERHADAP APLIKASI PINJAMAN ONLINE ILLEGAL SEBAGAI UPAYA PERLINDUNGAN KONSUMEN
}

\author{
Berlian Harina Sari ${ }^{1 凶}$ \\ ${ }^{1}$ Magister Hukum, Fakultas Hukum Universitas Sebelas Maret, Surakarta, Indonesia \\ berlianharina@gmail.com
}

\begin{abstract}
One of the impacts of globalization is the convenience for the community, one of which is to lend money based on technology or what is called Financial Technology, which one form of fintech is peer to peer lending (P2P lending).

The existence of P2P lending itself is increasingly mushrooming, especially in this era of the Covid-19 virus pandemic, especially those that are illegal by taking advantage of the economic difficulties of people affected by the Covid-19 pandemic.

But in reality, the losses caused by the presence of fintech are still often felt by the public.

The solution that can be given is how to improve the legal substance regarding fintech and P2P lending comprehensively, then for OJK is to issue an appeal for online platforms in Indonesia to collect loan recipients who fail to pay improperly through letters sent directly to all peer to peer lending platforms. in Indonesia. In addition to the existence of a code of conduct (guidelines of behavior) that must be obeyed by association members, so far the mitigation of a reasonable billing method is still using the code of ethics and the responsibility of the organizer.
\end{abstract}

Keywords: Law Enforcement, P2P lending.

Salah satu dampak globalisasi adalah kemudahan bagi masyarakat salah satunya untuk melakukan peminjaman uang berbasis teknologi atau yang disebut Financial Technologi, yang salah satu bentuk dari fintech ini adalah peer to peer lending (P2P lending).

Keberadaan P2P lending sendiri semakin menjamur terkhusus pada era pandemi virus Covid-19 ini, terkhusus yang bersifat ilegal dengan memaanfaatkan kesulitan ekonomi masyarakat yang terdampak pandemic Covid-19. Namun pada kenyataannya, kerugian yang diakibatkan oleh kehadiran fintech masih kerap dirasakan oleh masyarakat.

Solusi yang dapat diberikan adalah bagaimana memperbaiki substansi hukum mengenai fintech dan P2P lending secara komprehensif, kemudian bagi OJK adalah mengeluarkan himbauan bagi platform online di Indonesia dalam menagih penerima pinjaman yang gagal bayar secara tidak baik melalui surat yang dikirim langsung kepada seluruh platform peer to 
peer lending di Indonesia. Selain adanya code of conduct (pedoman perilaku) yang harus dipatuhi oleh anggota asosiasi, sejauh ini mitigasi cara penagihan yang wajar masih menggunakan kode etik dan tanggung jawab pihak penyelenggara.

Kata Kunci: Pinjaman, Online, Penegakan, Hukum.

\section{INTRODUCTION}

Pancasila adalah sumber dari segala sumber hukum. Pancasila sebagai Philosofische Grondslag pada dasarnya menghendaki negara yang memiliki Nilai Kebangsaan, Nilai Perikemanusiaan, Nilai Demokrasi, Nilai Kesejahteraan Sosial, dan Nilai Ketuhanan yang kemudian nilai-nilai ini digabungkan menjadi nilai gotong- royong yang mampu mengakomodasi segala kepentingan masyarakat Indonesia baik dalam konteks perorangan maupun bangsa dan negara. Gagasan Soekarno mengenai Pancasila ini disebut sebagai Soekarno sebagai kristalisasi nilai-nilai budaya asli masyarakat Indonesia sehingga Pancasila dapat dikatakan sebagai Philosofische Grondslag yang paling sesuai dengan Indonesia karena nilai-nilai Pancasila telah lebih dulu hidup bersama bangsa Indonesia sejak dahulu bahkan sebelum dirumuskannya Pancasila sendiri, sehingga dapat disimpulkan juga bahwa Pancasila telah menjadi jati diri, identitas, serta falsafah hidup masyarakat Indonesia. ${ }^{1}$ Dengan demikian merupakan hal yang wajar apabila Pancasila dijadikan sebagai bintang pemandu (leitstar), Philosofische Grondslag, dan cita hukum (rechtsidee) bagi hukum Indonesia.

Berbagai nilai yang terkandung dalam kelima sila Pancasila tersebut yang hendak diwujudkan secara nyata dalam berhukum di Indonesia kemudian terkongkritisasi dalam tujuan negara yang tertuang pada Alinea Keempat Pembukaan UUD NRI 1945. Adapun Alinea Keempat Pembuakaan UUD NRI 1945 Tahun 1945 menyatakan bahwa:

1. Melindungi segenap bangsa dan seluruh tumpah darah Indonesia;

2. Memajukan Kesejahteraan umum;

3. Mencerdaskan kehidupan bangsa;

4. Ikut melaksanakan ketertiban dunia, berdasarkan kemerdekaan, perdamaian abadi dan keadilan sosial.

Sehingga jelas juga bahwa politik hukum di Indonesia haruslah berlandaskan pada keempat prinsip tujuan negara yang terkandung di dalam Alinea Keempat Pembukaan UUD NRI tahun 1945. Hal ini dikarenakan dalam konteks politik hukum jelas bahwa hukum adalah "alat" yang berkerja dalam "sistem hukum" tertentu untuk mencapai "tujuan" negara atau "cita- cita" masyarakat Indonesia yang dengan demikian maka arah pembangunan dan pembaharuan hukum nasional haruslah bersumber dan berpegang pada nilai-nilai Pancasila dan tujuan negara itu termasuk dalam hal ini pembaharuan hukum di bidang perlindungan konsumen di Indonesia. ${ }^{2}$ Hal ini juga merupakan konsekuensi dari keberadaan Indonesia sebagai negara hukum sebagaimana tertera dalam Pasal 1 ayat (3)

${ }^{1}$ Alasan tersebut oleh Kaelan disebut dengan asal mula yang tidak langsung lahirnya Pancasila sekaligus sebagai kausa materialis. Lihat: Kaelan, Pendidikan Pancasila, Proses Reformasi, UUD Negara Amandemen 2002, Pancasila Sebagai Sistem Filsafat, Pancasila Sebagai Etika Politik, Paradigma Bermasyarakat, Berbangsa Dan Bernegara (Yogyakarta: Paradigma, 2004).

${ }^{2}$ Ibid, hlm. 17. 
UUD $\mathrm{NRI}^{3}$ yang selanjutnya wujud dari campur tangan negara dalam ini kemudian diwujudkan dalam bentuk kebijakan pemerintah salah satunya adalah peraturan perundangundangan di bidang perlindungan konsumen terkhusus dalam kaitannya dengan pinjaman online.

Tak dapat dipungkiri bahwa di era masa kini fenomena globalisasi merupakan fenomena khusus dalam peradaban manusia yang bergerak terus dalam masyarakat global dan merupakan bagian dari proses manusia global itu yang ditandai dengan kemajuan Ilmu Pengetahuan dan Teknologi (IPTEK) yang semakin mempercepat akselerasi globalisasi dan menyentuh seluruh aspek kehidupan. ${ }^{4}$

Berbicara mengenai globalisasi, pada dasarnya globalisasi merupakan era yang ditandai dengan kemajuan teknologi informasi, telekomunikasi, dan transportasi yang semakin pesat dan canggih, orientasi pemikiran, kepentingan, maupun segala daya upaya manusia untuk mewujudkan pemikiran dan mencapai kepentingannya itu cakupannya meliputi kawasan yang semakin mendunia dan menciptakan situasi dimana masyarakat di belahan dunia dapat dengan mudahnya. ${ }^{5}$

Dengan demikian dapat disimpulkan, bahwa keberadaan globalisasi telah merambat ke segala sector kehidupan dalam suatu negara yang pada dasarnya globalisasi terjadi akibat kemajuan teknologi atau sering disebut sebagai revolusi informasi, pemintaan pasar dunia, serta logika kapitalisme yang digerakakan oleh negara-negara imperial pusat, perusahaan multinasional dan bank-bank dengan dukungan lembaga-lembaga keuangan internasional dimana actor-aktor ini memiliki kekuasaan dalam mengatur formulasi strategis globalisasi, alokasi sumber daya ekonomi pada aktor-aktor global. ${ }^{6}$

Kemudahan dari globalisasi ini kemudian memunculkan kemudahan bagi masyarakat salah satunya untuk melakukan peminjaman uang berbasis teknologi atau yang disebut Financial Technologi, yang salah satu bentuk dari fintech ini adalah peer to peer lending (P2P lending/pinjaman online). Keberadaan P2P lending sendiri semakin menjamur terkhusus pada era pandemi virus Covid-19 ini, terkhusus yang bersifat ilegal dengan memaanfaatkan kesulitan ekonomi masyarakat yang terdampak pandemic Covid-19.7 Bahkan, pada periode Januari hingga Maret 2020, Satgas Waspada Investasi menemukan 508 P2P lending atau pinjaman online (pinjol) ilegal yang tidak terdaftar di Otoritas Jasa Keuangan (OJK) yang bila dikalkulasikan sejak tahun 2018, maka hingga tahun 2020, sudah ditemukan total 2406 pinjol ilegal. ${ }^{8}$

Semakin banyaknya bermunculan perusahaan fintech dalam bidang (peer-to- peer atau P2P lending) tentunya semakin mendapatkan perhatian publik dan pemerintah dalam hal ini regulator yakni Otoritas Jasa Keuangan (OJK) dan Bank Indonesia. Hal tersebut tertuang dalam Peraturan OJK Nomor 77/POJK.01/2016 tentang Layanan Pinjam

\footnotetext{
${ }^{3}$ Hilaire. Nigel D. White. McCoubrey, Textbook and Jurisprudence (London: Blackstone Press Limited, 1999).

${ }^{4}$ Suhartini, Perspektif Global (Yogyakarta: Fakultas Ilmu Komunikasi Universitas Negeri Yogyakarta, 2004).

${ }^{5}$ Marco P. Emil Salim, Sri Edi Swasono, Yudo Swasono, Tanri Abeng, Yaumil C. Agoes Achir and Sumampouw, Manajemen Dalam Era Globalisasi (Jakarta: Elex Media Komputindo, 1997).

${ }^{6}$ Arjun Appadurai, "Modernity at Large, Cultural Dimensions of Globalization," Public Worlds Volume 1 (2003).

${ }^{7}$ Dkk. Rayyan Sugangga, "Perlindungan Hukum Terhadap Pengguna Pinjaman Online (Pinjol) Ilegal," Jurnal Pakuan Justice Journal of Law Volume 01 (n.d.).

${ }^{8}$ Loc.Cit.,
} 
Meminjam Uang Berbasis Teknologi Informasi. ${ }^{9}$ Namun pada kenyataannya, kerugian yang diakibatkan oleh kehadiran fintech terkhusus pinjaman online illegal masih kerap dirasakan oleh masyarakat yang kemudian memunculkan pertanyaan, apakah keberadaan Peraturan OJK serta Undang-undang Perlindungan Konsumen sudah efektif dalam melindungi masyarakat dalam kaitannya dengan keberadaan pinjaman online ini atau belum.

Berdasarkan latar belakang tersebut maka penulis tertarik untuk mengkaji masalah ini dengan tulisan berjudul "Penegakan Hukum terhadap Aplikasi Pinjaman Online Ilegal sebagai Upaya Perrlindungan Hukum bagi Konsumen”.

\section{Rumusan Masalah}

a. Bagaimana dasar hukum dan realita pelaksanaan pinjaman online saat ini?

b. Bagaimana perlindungan konsumen mengenai pelaksanaan pinjaman online?

\section{RESULTS \& DISCUSSION}

Saat ini, era industri 4.0 sedang berlangsung pada berbagai aspek kehidupan, tidak terkecuali dunia bisnis. Para pelaku bisnis merespon cepat dengan berlomba-lomba melakukan perubahan konsep berbisnis dari konvensional (off- line) menjadi digital (online) untuk menghadapi persaingan usaha yang semakin ketat. ${ }^{10}$ Sektor keuangan sendiri merupakan salah satu sektor usaha yang mengalami perubahan signifikan, yaitu dengan kehadiran Fin'Tech untuk menjawab permasalahan akses keuangan masyarakat pada lembaga keuangan konvensional. ${ }^{11}$ Sebelumnya, berhubungan dengan lembaga keuangan (perbankan) konvensional merupakan hal yang cukup rumit dan menghabiskan waktu yang cukup lama. Oleh karena itu, FinTech menawarkan kemudahan dan kecepatan dalam proses transaksi keuangan masyarakat, khususnya peminjaman dana. ${ }^{12}$

Menurut Pasal 3 Peraturan Bank Indonesia Nomor 19/12/PBI/2017 tentang Penyelenggaraan Teknologi Finansial penyelenggaraan Fintech dikategorikan menjadi 5, yaitu: ${ }^{13}$

1. Sistem pembayaran mencakup otorisasi, kliring, penyelesaian akhir, dan pelaksanaan pembayaran,

2. Pendukung pasar merupakan teknologi finansial yang menggunakan teknologi informasi dan/atau teknologi elektronik untuk memfasilitasi pemberian informasi

9 Agus Priyonggojati, "Perlindungan Hukum Terhadap Penerima Pinjaman Dalam Penyelenggaraan Financial Technology Berbasis Peer To Peer Lending," Jurnal USM Law Review Vol 2 No 2 (2019).

${ }^{10}$ Darman, "Financial Technology (FinTech): Karakteristik Dan Kualitas Pinjaman Pada Peer to Peer Lending Di Indonesia,” Jurnal Manajemen Teknologi Vol. 18 No (2019).

11 Ibid.,

12 \& Merlino. Saksonova, S., Kuzmina, I., "Fintech as Financial Innovation - the Possibilities and Problems of Implementation,” European Studies Journal XX (3A) (2017).

${ }^{13}$ Windy Sonya Novita, "Aspek Hukum Peer to Peer Lending (Identifikasi Permasalahan Hukum Dan Mekanisme Penyelesaian),” Jurnal Privat Law Vol. VIII (2020) 
yang lebih cepat dan lebih murah terkait dengan produk dan/atau layanan jasa keuangan kepada masyarakat,

3. Manajemen investasi dan manajemen risiko antara lain penyediaan produk investasi online dan asuransi online,

4. Pinjaman, pembiayaan, dan penyediaan modal antara lain layanan pinjam meminjam uang berbasis teknologi informasi (Peer to Peer Lending) serta pembiayaan atau penggalangan dana berbasis teknologi informasi (crowdfunding), dan

5. Jasa finansial lainnya yang merupakan teknologi finansial selain kategori sistem pembayaran, pendukung pasar, manajemen investasi dan manajemen risiko, serta pinjaman, pembiayaan, dan penyediaan modal. Sektor yang cukup diminati adalah sektor pinjaman, pembiayaan dan penyediaan modal, salah satu produknya adalah layanan pinjam meminjam uang berbasis teknologi informasi atau Peer to Peer Lending yang selanjutnya disebut P2P Lending.

Maraknya pertumbuhan P2P Lending sendiri terlihat dari data OJK yang menunjukkan bahwa P2P Lending menunjukkan trend yang sangat positif, tercatat hingga bulan September 2017 pertumbuhan penyaluran dana melalui Peer to Peer Lendingdi Indonesia mencapai 1,6 triliun rupiah. Sementara itu, pendanaan di luar Pulau Jawa meningkat sebesar $1.074 \%$ (seribu tujuh puluh empat persen) sejak akhir tahun lalu menjadi Rp 276 miliar (dua ratus tujuh puluh enam miliar rupiah). Hal tersebut didukung adanya peningkatan jumlah pemberi pinjaman di luar pulau jawa sebesar 784\% (tujuh puluh delapan persen) begitu juga dengan jumlah peminjam yang meningkat sebesar $745 \%$ (tujuh ratus empat puluh lima persen). ${ }^{14}$

Tidak hanya di Indonesia, di negara lain pun perkembangan industry P2P lending sendiri sangat pesat misalnya seperti pada negara China dimana peningkatan P2P di China sendiri disebabkan karena beberapa faktor seperti: ${ }^{15}$

1. Tingkat penetrasi internet di Cina sudah mencapai 56 persen pada tahun 2018 .

2. Adanya pasokan besar dana yang tersedia dari investor.

3. Tuntutan keuangan dari perusahaan kecil hingga menengah yang tidak dapat dipenuhi oleh sistem perbankan yang ada.

Di China sendiri seperti juga terjadi di seluruh Negara, pinjaman P2P lebih bersahabat dengan bisnis kecil karena bank- bank besar di China umumnya lebih suka perusahaan milik negara atau perusahaan besar, dimana sekitar 70 persen pinjaman dari bank tersebut adalah pinjaman komersial, dengan hanya 30 persen untuk perorangan. ${ }^{16}$

Dasar hukum dari pinjaman online sendiri diatur di dalam Peraturan Otoritas Jasa Keuangan Nomor 77/POJK.01/2016 tentang Layanan Pinjam Meminjam Uang Berbasis Teknologi Informasi. Pada Pasal 1 Angka 3 POJK 77/POJK.01/2016 yang menyebutkan bahwa Layanan Pinjam Meminjam Uang Berbasis Teknologi Informasi adalah penyelenggaraan layanan jasa keuangan untuk mempertemukan pemberi pinjaman dengan penerima pinjaman dalam rangka melakukan perjanjian pinjam meminjam dalam mata uang rupiah secara langsung. Hal ini sekaligus menjelaskan bahwa P2P lending merupakan

${ }^{14}$ Adi Setiadi Saputra, "Perlindungan Terhadap Pemberi Pinjaman Selaku Konsumen Dan Tanggung Jawab Penyelenggara Peer to Peer Lending Dalam Kegiatan Peer to Peer Lending Di Indonesia," Jurnal VeJ Volume 5 N (n.d.).

15 "Peer to Peer Lending (P2P) Pelajaran Dari China," Jurnal LPPI No A.13 Ap (2019).

16 Ibid., 
teknologi yang dapat memfasilitasi kebutuhan teknologi yang dapat memfasilitasi kebutuhan finansial masa kini. ${ }^{17}$

Model bisnis P2P Lending sendiri yaitu: ${ }^{18}$

1. Calon Penerima Pinjaman melakukan registrasi di platform, kemudian mengajukan pinjaman melalui platform.

2. Penyelenggara kemudian melakukan verifikasi data calon Penerima Pinjaman, kemudian menampilkan pengajuan pinjaman di platform marketplace.

3. Pemberi Pinjaman melakukan registrasi di platform, kemudian dapat memilih pinjaman mana yang akan didanai di platform marketplace dan melakukan pendanaan.

4. Penerima Pinjaman akan mendapatkan pinjaman dana dari Pemberi Pinjaman sesuai dengan jumlah dan jangka waktu yang disepakati.

Dengan mekanisme pendaftaran demikian maka terlihat bagaimana P2P lending sangat memudahkan penerima pinjaman terkhusus pelaku usaha untuk mendapatkan modal dalam waktu yang relatif lebih singkat dengan prosedur yang mudah.

Selanjutnya mengenai perjanjian pinjam meminjam sendiri diatur pula dalam Pasal 20 Peraturan OJK 77/POJK.01/2016 yaitu:

1. Perjanjian pemberian pinjaman antara Pemberi Pinjaman dengan Penerima Pinjaman dituangkan dalam Dokumen Elektronik.

2. Dokumen Elektronik sebagaimana dimaksud pada ayat (1) wajib paling sedikit memuat:
a. nomor perjanjian;
b. tanggal perjanjian;
c. identitas para pihak;
d. ketentuan mengenai hak dan kewajiban para pihak;
e. jumlah pinjaman;
f. suku bunga pinjaman;
g. nilai angsuran;
h. jangka waktu;
i. objek jaminan (jika ada);
j. rincian biaya terkait;
k. ketentuan mengenai denda (jika ada); dan 1. mekanisme penyelesaian sengketa.

3. Penyelenggara wajib menyediakan akses informasi kepada Penerima Pinjaman atas posisi pinjaman yang diterima.

Lebih lanjut lagi, dalam pinjaman online Penyelenggara wajib menerapkan prinsip dasar dari perlindungan Pengguna yaitu:

1. Transparansi;

2. Perlakuan yang adil;

3. Keandalan;

4. Kerahasiaan dan keamanan data; dan

${ }^{17}$ Rodes Ober Adi Guna Pardosi, "Perlindungan Hak Pengguna Layanan Pinjaman Online," JURNAL HAM Desember 2 (n.d.).

${ }^{18}$ Novita, "Aspek Hukum Peer to Peer Lending (Identifikasi Permasalahan Hukum Dan Mekanisme Penyelesaian)." 
5. Penyelesaian sengketa Pengguna secara sederhana, cepat, dan biaya terjangkau.

Pada pelaksanaan P2P lending di Indonesia pemberi pinjaman memiliki tingkat risiko yang sangat tinggi dikarenakan pemberi pinjaman memberikan pinjaman tanpa agunan dan tidak mengenal langsung peminjam, pemberi pinjaman hanya mengetahui informasi tentang peminjam berdasarkan informasi yang ada di platform P2P lending, akan tetapi hal ini diacuhkan mengingat P2P lending memberikan keuntungan dari suku bunga yang tinggi, lebih tinggi daripada instrumen investasi biasa, suku bunga peer to peer lending di Indonesia saat ini mencapai 20\% (dua puluh persen) bahkan lebih. ${ }^{19}$

Dan agar pelaksanaan dari penyelenggaraan pinjaman online berjalan dengan lancer, terdapat larangan-larangan yang harus diikuti oleh pemberi pinjaman yang diatur di dalam Pasal 43 Peraturan OJK 77/POJK.01/2016 yang mengatur bahwa:

Dalam menjalankan kegiatan usaha, Penyelenggara dilarang:

a. Melakukan kegiatan usaha selain kegiatan usaha Penyelenggara yang diatur dalam peraturan OJK ini;

b. Bertindak sebagai Pemberi Pinjaman atau Penerima Pinjaman;

c. Memberikan jaminan dalam segala bentuknya atas pemenuhan kewajiban pihak lain;

d. Menerbitkan surat utang;

e. Memberikan rekomendasi kepada Pengguna;

f. Mempublikasikan informasi yang fiktif dan/atau menyesatkan;

g. Melakukan penawaran layanan kepada Pengguna dan/atau masyarakat melalui sarana komunikasi pribadi tanpa persetujuan Pengguna; dan

h. Mengenakan biaya apapun kepada Pengguna atas pengajuan pengaduan.

Pengaturan mengenai pinjaman online sendiri merupakan perwujudan dari upaya perlindungan konsumen yaitu dalam hal ini adalah penerima pinjaman. Definisi dari Perlindungan Konsumen sendiri diatur dalam Undang-Undang nomor 8 tahun 1999 tentang Perlindungan Konsumen ("UU Perlindungan Konsumen") Dalam UU Perlindungan Konsumen dinyatakan bahwa, perlindungan konsumen adalah segala upaya yang menjamin adanya kepastian hukum untuk memberi perlindungan kepada konsumen. Dengan demikian maka cakupan perlindungan konsumen itu dapat dibedakan dalam dua aspek, yaitu: ${ }^{20}$

1. Perlindungan terhadap kemungkinan barang yang diserahkan kepada konsumen tidak sesuai dengan apa yang telah disepakati.

2. Perlindungan terhadap diberlakukannya syarat-syarat yang tidak adil kepada konsumen.

Berakar pada definisi dari perlindungan konsumen itu, maka pada dasarnya perlindungan konsumen dilakukan dengan: ${ }^{21}$

1. Menciptakan system perlindungan konsumen yang mengandung unsur keterbukaan akses informasi, serta menjamin kepastian hukum.

2. Melindungi kepentingan konsumen pada khususnya dan kepentingan seluruh pelaku usaha.

19 Saputra, "Perlindungan Terhadap Pemberi Pinjaman Selaku Konsum. Dan Tanggung Jawab Penyelenggara Peer to Peer Lend. Dalam Kegiat. Peer to Peer Lend. Di Indones.”

${ }^{20}$ Adrianus Meliala, Praktik Bisnis Curang (Jakarta: Pustaka Sinar Harapan, n.d.).

21 Abdul Halim Barkatulah, Hukum Perlindungan Konsumen (Kajian Teoretis Dan Perkembangan Pemikiran) (Bandung: Nusa Media, 2008). 
3. Meningkatkan kualitas barang dan pelayanan jasa.

4. Memebrikan perlindungan kepada konsumen dari praktik usaha yang menipu dan menyesatkan.

5. Memadukan penyelenggaraan, pengembangan, dan pengaturan perlindungan konsumen dengan bidang-bidang perlindungan pada bidang-bidang lainnya.

Selanjutnya dari sisi hukum perikatan, berbicara mengenai perjanjian pinjam meminjam, ketentuan pinjam meminjam sendiri diatur dalam Pasal 1754 Kitab UndangUndang Hukum Perdata yang mengatur bahwa:

"Pinjam pakai habis adalah suatu perjanjian, yang menentukan pihak pertama yang mengajukan barang yang dapat diselesaikan terpakai kepada pihak kedua dengan persyaratan kedua akan membawa barang- barang ke jumlah pertama dan jumlah ke dua."

Meskipun Pasal 1754 KUHPerdata tidak menyebutkan secara spesifik mengenai uang, tetapi objek utama dari perjanjian ini adalah barang yang dapat habis dalam pemakaian ataupun barang yang dapat diganti dengan keadaan dan jenis yang sama maupun berupa uang. Dengan demikian dapat disimpulkan bahwa peminjaman uang termasuk pada perjanjian peminjaman pada umumnya. ${ }^{22}$ Oleh karena itu, segala ketentuan yang berkaitan dengan perjanjian pinjam-meminjam barang yang habis terpakai, berlaku juga terhadap persetujuan peminjaman uang. ${ }^{23}$

Tidak hanya itu, berkaitan dengan bunga yang dikenakan kepada penerima pinjaman dalam suatu perjanjian pinjam meminjam pun sebenarnya telah diatur berdasarkan ketentuan Pasal 1765 KUHPerdata yang menyebutkan adalah diperbolehkan memperjanjikan bunga atas peminjaman uang atau lain barang yang menghabis karena pemakaian ${ }^{24}$ namun dengan ketentuan mengenai besarnya bunga yang diperjanjikan "mesti dinyatakan secara tertulis". 25

Selanjutnya karena bentuknya perjanjian, maka mengenai syarat sahnya perjanjian sendiri diatur di dalam Pasal 1320 KUH Perdata yaitu adanya kesepakatan, kecakapan untuk membuat perjanjian, suatu hal tertentu, dan suatu sebab yang dilarang. Dengan mengacu pada definisi dari perjanjian pinjam meminjam maupun syarat sahnya perjanjian dalam KUH Perdata ini, maka dapat disimpulkan bahwa pada dasarnya perjanjian pinjaman online adalah sah secara hukum.

Dengan demikian dapat disimpulkan bahwa pada pelaksanaan P2P lending hubungan hukum antara pemberi pinjaman dan penyelenggara adalah pemberi pinjaman memanfaatkan jasa platform P2P lending yang mempertemukan pemberi pinjaman dengan penerima pinjaman, untuk setiap transaksi P2P lending yang berhasil pemberi pinjaman dibebankan bayaran berupa biaya layanan (service fee/service charge) oleh penyelenggara. ${ }^{26}$ Maka dalam penyelenggaraan P2P lending memiliki inti hubungan timbal balik antara pemberi dan penerima pinjaman yaitu antara lain: ${ }^{27}$

${ }^{22}$ Novita, Op.Cit.,

${ }^{23}$ H.A. Dardiri Hasyim, Hukum Perikatan Dan Perjanjian (Surakarta: Penerbitan dan Percetakan UNS (UNS Press), 2015).

${ }^{24}$ Novita, Op.Cit.,

${ }^{25}$ M. Yahya Harahap, Segi-Segi Hukum Perjanjian (Bandung: Alumni, 1986).

26 Saputra, "Perlindungan Terhadap Pemberi Pinjaman Selaku Konsum. Dan Tanggung Jawab Penyelenggara Peer to Peer Lend. Dalam Kegiat. Peer to Peer Lend. Di Indones.”

${ }^{27}$ Ibid., 
1. Selain mengoperasikan platform P2P lending, penyelenggara memiliki tanggung jawab untuk melaksanakan analisis kredit terhadap pihak-pihak yang akan mengajukan pinjaman peer to peer lending.

2. Peminjam yang dapat mengajukan pinjaman kedalam platformpeerto peer lending adalah peminjam yang telah melewati analisis kredit dan syarat-syarat yang telah ditentukan oleh penyelenggara peer to peer lending.

3. Penyelenggara P2P lending bertanggung jawab kepada pemberi pinjaman selaku konsumen, dalam melakukan seleksi pihak-pihak yang akan mengajukan pinjaman lewat platform peer to peer lendingyang dikelolanya.

Namun pada praktiknya, permasalahan berkaitan dengan pinjaman online masih kerap terjadi di masyarakat dan cenderung merugikan masyarakat. Pada kenyataannya faktor terbesar mengapa kasus ini dapat terjadi adalah akibat banyak masyarakat Indonesia yang masih belum paham tentang bisnis ini tetapi sudah mulai terjun langsung dalam bisnis ini. Sehingga masih banyak masyarakat yang terjebak dalam bisnis Platform-platform illegal serta complain terhadap bunga yang besar. Padahal, hal ini sebetulnya tidak akan terjadi apabila masyarakat terlebih dahulu mengecek platform tersebut sudah terdaftar di OJK atau belum. ${ }^{28}$

Selanjutnya permasalahan juga semakin diperumit akibat kasus gagal bayar dimana Penerima Pinjaman tidak mampu mengembalikan pinjamannya sesuai dengan jangka waktu yang telah disepakati dalam perjanjian. Akhirnya hal ini menimbulkan masalah baru terkait cara-cara penagihan yang tidak patut yang dilakukan oleh Penyelenggara P2P Lending seperti penyebaran data, penindasan dan penagihan dengan cara yang tidak layak terhadap penerima pinjaman. ${ }^{29}$

Contoh kasus mengenai pinjaman online illegal initerlihat dari apa yang dialami oleh Shinta Bawole, warga Makassar yang menjadi korban pinjaman online. ${ }^{30}$ Ia terpaksa mengembalikan pinjaman sebesar Rp 700.000 dan mengaku hanya menerima uang Rp 400.000. Shinta mengaku, dirinya mengunduh aplikasi pinjol Tunaicepat dari Playstore dan merasa tidak pernah menyetujui pinjaman tersebut. Namun entah mengapa, dirinya mendapat pesan singkat yang menjelaskan bahwa pengajuan pinjamannya telah disetujui dan dana telah ditransfer ke rekeningnya.

Hal serupa dialami oleh seorang wanita yang bekerja sebagai guru honorer di Kabupaten Semarang terjerat pinjaman online (pinjol). Dia yang awalnya meminjam Rp 3,7 juta dan kini membengkak menjadi Rp 206,3 juta. ${ }^{31}$ Guru honorer bernama Afifah Muflihati ini mengatakan awalnya pada tanggal 30 Maret 2021 ia memang sedang membutuhkan uang. Kemudian ada iklan di telepon selulernya yang merujuk pada sebuah aplikasi pinjaman online yang menjanjikan pinjaman sebesar Rp 5 juta tenor 91 hari bunga 0,4 persen. Dalam aplikasi pinjol yang diunduh Afifah itu ternyata terhubung dengan aplikasi pinjol lainnya.

${ }^{28}$ Dona Budi Kharismai, "Problematika Mekanisme Penyelesaian Pinjaman Gagal Bayar Pada Pinjaman Online Di Indonesia,” Jurnal Rechtsvinding 7 April (2020).

${ }^{29}$ Novita, Op.Cit.,

${ }^{30}$ Rachmawati, "5 Cerita Mereka Yang Terjerat Pinjaman Online, Ada Yang Bunuh Diri Hingga Merampok Untuk Bayar Utang," Kompas, n.d., https://regional.kompas.com/read/2021/05/20/060700978/5-cerita-merekayang-terjerat-pinjaman-online-ada-yang-bunuh-diri-hingga?page=all.

${ }^{31}$ Angling Adhitya Purbaya, "Guru Honorer Di Semarang Terjerat Pinjol, Utang Rp 3,7 Juta Bengkak Rp 206 Juta," Detik.Com, 2021, https://news.detik.com/berita-jawa-tengah/d-5592751/guru-honorer-di-semarangterjerat-pinjol- utang-rp-37-juta-bengkak-rp-206-juta. 
Setelah mengikuti syarat peminjaman, akhirnya uang langsung ditransfer ke rekening Afifah Rp 3,7 juta, padahal ia berharap dapat Rp 5 juta. Dan ternyata ia dipaksa membayar sebesar Rp 206,3 juta. Lebih lanjut, Ia panik karena teror mulai berdatangan bahkan datanya sudah disebar. Pihak pinjol juga ternyata bisa mengakses kontak telepon Afifah sehingga dikirimkan foto Afifah beserta KTP dengan narasi tidak bisa bayar utang, bahkan sampai fitnah Afifah jual diri demi bayar utang.

Hal ini tentu menunjukkan pada praktiknya keberadaan P2P lending atau pinjaman online ini masih belum bersesuaian dengan perlindungan bagi konsumen sebagaimana tertuang di dalam UU Perlindungan Konsumen. Dimana pada pasal 4 UU Perlindungan Konsumen telah diatur bahwa Hak konsumen antara lain adalah:

1. Hak atas kenyamanan, keamanan, dan keselamatan dalam mengkonsumsi barang dan/atau jasa;

2. Hak untuk memilih barang dan/atau jasa serta mendapatkan barang dan/atau jasa tersebut sesuai dengan nilai tukar dan kondisi serta jaminan yang dijanjikan;

3. Hak atas informasi yang benar, jelas, dan jujur mengenai kondisi dan jaminan barang dan/atau jasa;

4. Hak untuk didengar pendapat dan keluhannya atas barang dan/atau jasa yang digunakan;

5. Hak untuk mendapatkan advokasi, perlindungan, dan upaya penyelesaian sengketa perlindungan konsumen secara patut;

6. Hak untuk mendapat pembinaan dan pendidikan konsumen;

7. Hak untuk diperlakukan atau dilayani secara benar dan jujur serta tidak diskriminatif;

8. Hak untuk mendapatkan kompensasi, ganti rugi dan/atau penggantian, apabila barang dan/atau jasa yang diterima tidak sesuai dengan perjanjian atau tidak sebagaimana mestinya;

9. Hak-hak yang diatur dalam ketentuan peraturan perundang-undangan lainnya.

Tidak hanya itu, UU Perlindungan Konsumen juga mengatur tujuan dari perlindungan konsumen dimana dalam UU Perlindungan Konsumen dikatakan:

"Perlindungan konsumen bertujuan:

1. Meningkatkan kesadaran, kemampuan dan kemandirian konsumen untuk melindungi diri.

2. Mengangkat harkat dan martabat konsumen dengan cara menghindarkannya dari ekses negatif pemakaian barang dan/atau jasa.

3. Meningkatkan pemberdayaan konsumen dalam memilih, menentukan, dan menuntut hak-haknya sebagai konsumen.

4. Menciptakan sistem perlindungan konsumen yang mengandung unsur kepastian hukum dan keterbukaan informasi serta akses untuk mendapatkan informasi.

5. Menumbuhkan kesadaran pelaku usaha mengenai pentingnya perlindungan konsumen sehingga tumbuh sikap yang jujur dan bertanggungjawab dalam berusaha,

6. Meningkatkan kualitas barang dan/atau jasa yang menjamin kelangsungan usaha produksi barang dan/atau jasa, kesehatan, kenyamanan, keamanan, dan keselamatan konsumen. 
Mengacu pada tujuan perlindungan konsumen dan hak-hak tersebut maka semua pelaku usaha yang menjalankan kegiatan usahanya di Indonesia harus memiliki batasan berupa pengaturan tanggung jawab dalam menjalankan usahanya untuk mencapai tujuan dari perlindungan konsumen mengingat kedudukan konsumen selalu menjadi pihak yang lebih lemah dibandingkan pelaku usaha, baik secara pengetahuan maupun secara ekonomi yangmana hal ini kemudian menjadi landasan dari lahirnya UU Perlindungan Konsumen sebagai penyeimbang kedudukan antara konsumen dan pelaku usaha. ${ }^{32}$

Selanjutnya mengenai perlindungan hukum sendiri, Satjipto Rahardjo dalam pandangannya mengenain filosofi hukum menyatakan bahwa "Hukum untuk manusia, bukan manusia untuk hukum,". ${ }^{33}$ Hukum bertugas untuk melayani masyarakat dan bukan sebaliknya. Kualitas suatu hukum ditentukan dengan kemampuannya untuk mengabdi pada kesejahteraan manusia. ${ }^{34}$

Apabila manusia adalah untuk hukum, maka dinamika masyarakat akan terhambat, bahkan mungkin berhenti, saat dihadapkan dengan hukum yang mempertahankan status quo. Sebaliknya, apabila hukum adalah untuk manusia, maka ia tidak boleh menjadi hambatan untuk menyalurkan dinamika masyarakat. ${ }^{35}$

Dengan demikian maka dalam konsepsi negara hukum Pancasila kemudian menempatkan segala sesuatu haruslah berdasar pada hukum. Hukum sendiri merupakan salah satu instrumen untuk mencapai ketertiban yang substansinya haruslah mencerminkan apa yang dibutuhkan oleh masyarakat. ${ }^{36}$ Hukum pada umumnya diartikan sebagai keseluruhan peraturan atau kaedah dalam kehidupan yang dipaksakan pelaksanaannya. Untuk itu, dalam kehidupan masyarakat yang semakin kompleks, hukum semestinya mengikuti perkembangan dari masyarakat karena sebagaimana disampaikan oleh Sizheimer bahwa hukum tidak bergerak dalam ruang yang hampa dan berhadapan dengan hal-hal yang abstrak. Melainkan, ia selalu berada dalam suatu tatanan sosial tertentu dan manusiamanusia yang hidup. ${ }^{37}$

Kedudukan negara dalam mengatur perekonomian ini sesuai dengan Konsep Negara Kesejahteraan (welvaartsstaat, Welfare State) yang dianut oleh Indonesia dimana konsep negara kesejahteraan pada dasarnya menghendaki adanya pengaturan yang dilakukan oleh pemerintah dalam rangka upaya untuk mewujudkan kesejahteraan itu sendiri dimana kedudukan negara yang sebelumnya terbatas pada penjaga ketertiban semata kemudian diperluas dengan memberikan kewenangan yang lebih besar pada negara untuk mengatur perekonomian masyarakat. ${ }^{38}$

Konsekuensi dari perluasan kewenangan inilah yang kemudian menjadikan kepentingan umum sebagai asas hukum publik tidak lagi diartikan sebagai kepentingan

\footnotetext{
32 Saputra, Op.Cit.,

${ }^{33}$ Satjipto Rahardjo, Penegakkan Hukum Progresif, Penerbit Buku Kompas, 2010.

${ }^{34}$ Suteki, Desain Hukum Di Ruang Sosial (Yogyakarta: Thafa Media, 2013).

${ }^{35}$ Satjipto Rahardjo, Biarkan Hukum Mengalir (Jakarta: Kompas, 2008).

${ }^{36}$ Soedikno Mertokusumo, Mengenal Hukum Suatu Pengantar (Yogyakarta: Liberti, 1986).

37 Satjipto Rahardjo, "Hukum Dalam Kerangka Ilmu-Ilmu Sosial Budaya," Majalah Ilmiah MasalahMasalah Hukum nomor 1 ta (1972).

${ }^{38}$ Konsep negara kesejahteraan pertama kali lahir setelah berakhirnya Perang Dunia II dimana konsep ini lahir dari kegagalan di bidang sosial, politik, dan ekonomi masyarakat pada sistem politik dan ekonomi kapitalis yang bebas dengan bertumpu pada konsep negara hukum liberal yang meletakkan peran negarasebagai "negara penjaga malam" (nachtwakerstaat). Lihat: Aminuddin. Ilmar, Hak Menguasai Negara Dalam Privatisasi BUMN (Jakarta: Kencana, 2012).
} 
negara sebagai kekuasaan yang menjaga ketertiban atau kepentingan kaum borjuis sebagai basis masyarakat dari negara hukum liberal, melainkan dimaknai sebagai kepentingan dari "gedemocratiseerde nationale staat, waarvan het bele volk in al zijn geledin gen deel uitmaaket" yang berarti seluruh rakyat dalam semua tingkatan adalah bagian dari negara untuk menciptakan keadilan sosial bagi seluruh rakyat melalui tugas servis negara (social service state) yang diwujudkan melalui pembangunan dan peningkatan kesejahteraan masyarakat melalui pemberian peran yang lebih penting kepada negara dalam memberikan pelayanan sosial kepada warganya. Dengan demikian pemerintah dihendaki untuk berperan aktif dalam kehidupan ekonomi dan sosial masyarakat di samping menjaga ketertiban dan keamanan (rust en orde) ${ }^{39}$ dimana Keamanan yang dimaksud termaksud pula sebagai keamanan sosial di segala bidang kemasyarakatan dalam suatu welfare state. ${ }^{40}$

Negara, melalui OJK sebenarnya telah memiliki instrumen hukum untuk mengatur pinjol, bahkan sudah dibentuk Satgas Waspada Investasi yang beranggotakan OJK dan instansi lainnya. ${ }^{41}$ Satgas Waspada Investasi sendiri merupakan hasil kolaborasi OJK bersama dengan Kementerian Perdagangan, Kementerian Komunikasi dan Informatika, Kementerian Koperasi dan Usaha Kecil dan Menengah, Kejaksaan, Kepolisian RI, dan Badan Koordinasi Penanaman Modal (BKPM) sebagai bentuk komitmen untuk memperkuat kerjasama dalam Satuan Tugas/Satgas Waspada Investasi untuk mencegah dan menangani maraknya tawaran dan praktek investasi ilegal, termasuk untuk menangani pinjol ilegal.

Satgas Waspada Investasi memiliki fungsi pencegahan dan dan penanganan tindakan melawan hukum di bidang penghimpunan dana masyarakat dan pengelolaan investasi. Secara umum kegiatan pencegahan dilakukan dengan cara edukasi dan sosialisasi serta pemantauan potensi dugaan tindakan melawan hukum. Untuk kegiatan penangan secara umum dilakukan dengan inventarisasi, analisis, menghentikan/menghambat tindakan melawan hukum di bidang penghimpungan dana masyarakat dan pengelolaan investasi, melakukan pemeriksaan dugaan pelanggaran, menelusuri situs situs yang berpotensi merugikan dan menyusun rekomendasi tindak lanjut penanganan. ${ }^{42}$

Keberadaan Satgas Waspada Investasi sendiri sebenarnya sudah menunjukkan upaya perlindungan hukum terhadap fintech terkhusus yang sifatnya illegal yang dibuktikan bahwa sejak periode Agustus 2018 hingga akhir 2019 tercatat sudah ada 4.020 finansial teknologi ilegal termasuk pinjol ilegal yang diblokir oleh anggota Satgas Waspada Investasi yaitu

${ }^{39}$ S. F. Marbun, Hukum Administrasi Negara I (Yogyakarta: FH UII Press, 2012).

${ }^{40}$ Peran negara dalam konsep negara kesejahteraan yang dirumuskan dalam pembukaan UUD NRI 1945 ini kemudian menjadi landasan pemikiran dari founding fathers bangsa Indonesia dimana kedudukan negara ini oleh Moh. Hatta disebutkan bahwa UUD NRI 1945 mengandung semangat ke arah pembentukan model negara kesejahteraan dengan tujuan-tujuan yang hendak dicapai yaitu. Pertama, untuk mengontrol dan mendayagunakan sumber daya sosial ekonomi untuk kepentingan public. Kedua, untuk menjamin distribusi kekayaan secara adil dan merata. Ketiga, untuk mengurangi kemiskinan. Keempat, untuk menyediakan asuransi sosial (pendidikan dan kesehatan) bagi masyarakat miskin. Kelima, untuk menyediakan subsidi untuk layanan sosial dasar bagi disadvantage people. Keenam, untuk memberi proteksi sosial bagi setiap warga negara. Lihat: M. Marilang, "IDEOLOGI WELFARE STATE KONSTITUSI: HAK MENGUASAI NEGARA ATAS BARANG TAMBANG,” Jurnal Konstitusi, 2012, https://doi.org/10.31078/jk.

${ }^{41}$ Rayyan, Op.Cit.,

42 Ibid., 
Kementerian Kominfo. ${ }^{43}$ Walaupun kemudian kesulitan selanjutnya adalah, seski sudah banyak dilakukan pemblokiran, pinjol ilegal baru tetap bermunculan, hal ini dimungkinkan karena secara teknologi memang tidak sulit. Secara praktis, developer aplikasi pinjol yang telah diblokir, dengan mudahnya dapat mendevelop aplikasi pinjol lagi dengan referensi source code aplikasi yang sama (copy paste), melakukan sedikit kustomisasi diakhir dengan memberikan nama/brand pinjol online baru. ${ }^{44} \mathrm{Hal}$ ini sekaligus menunjukkan bahwa selain mekanisme represif seperti pembentukan Satgas Waspada Investasi, maka diperlukan pembaharuan terkait syarat pendirian dan perizinan fintech terkhusus P2P lending ini sekaligus sosialisasi kepada masyarakat untuk lebih waspada terhadap keberadaan P2P lending ini. Dengan demikian dapat mewujudkan amanat POJK Nomor 77/POJK.01/2016 yang mengatur prinsip dasar dari perlindungan pengguna, antara lain:

1. Transparansi;

2. Perlakuan yang adil;

3. Keandalan;

4. Kerahasiaan dan keamanan data;

5. Penyelesaian sengketa Pengguna secara sederhana, cepat, dan biaya terjangkau.

Namun sayangnya, mengenai gagal bayar yang kerap menjadi permasalahan antara konsumen dan pemberi pinjaman online, hingga saat ini belum terdapat pengaturan yang komprehensif yang diatur oleh OJK. Hal ini dikarenakan menurut OJK bukan sesuatu yang menjadi urgensi untuk dibuatkan suatu peraturan. Hal ini didukung juga karena belum adanya undang-undang yang mengatur khusus tentang Financial Technology. ${ }^{45}$

Lawrence M Friedman dalam teori Subsistem Hukum yang menyatakan bahwa berhasil atau tidaknya penegakan hukum bergantung pada ketiga komponen tersebut karena ketiganya saling berkaitan satu sama lainnya. ${ }^{46}$ Friedman berpendapat bahwa substansi hukum disebut sebagai sistem substansial yang menentukan bisa atau tidaknya hukum itu dilaksanakan, struktur hukum memegang peran esensial dalam menentukan bisa atau tidaknya hukum itu dilaksanakan dengan baik dan budaya hukum juga turut berpengaruh karena bertitik pada sikap manusia terhadap hukum dan sistem hukum-kepercayaan, nilai, pemikiran, serta harapannya. ${ }^{47}$

Kultur hukum adalah suasana pemikiran sosial dan kekuatan sosial yang menentukan bagaimana hukum digunakan, dihindari, atau disalahgunakan dan sangat mempengaruhi bekerjanya hukum adalah kultur hukum. Kultur hukum inilah yang berfungsi sebagai jembatan yang menghubungkan antara peraturan hukum dengan tingkah laku hukum seluruh warga masyarakat. ${ }^{48}$

43 https://www.ojk.go.id/waspada-investasi/id/tentang/pages/Fungsi-dan-Tugas-Satgas.aspx (Fungsi dan Tugas Satgas,

44 Rayyan, Op.Cit.,

45 Dona, Op.Cit.,

${ }^{46}$ Lawrence M. Friedmann, Das Rechtssystem Im Blickfeld Der Sozialwissenschaften, Das Rechtssystem Im Blickfeld Der Sozialwissenschaften, 2020, https://doi.org/10.3790/978-3-428-44948-4.

47 Leony Sondang Suryani, "Implikasi Putusan Mahkamah Konstitusi No 22/PUU-XV/2017 Tentang Pengujian UU Perkawinan Mengenai Batas Usia Perkawinan Terhadap Pemenuhan Dan Perlindungan Hak Anak Perempuan" (Diponegoro, 2019).

48 Slamet Tri Wahyudi, "Problematika Penerapan Pidana Mati Dalam Konteks Penegakan Hukum Di Indonesia," Jurnal Hukum Dan Peradilan Volume 1, (2012). 
Untuk itu selain adanya substansi hukum yang komprehensif dan struktur hukum yang tegas, diperlukan adanya peningkatan kesadaran masyarakat. ${ }^{49}$

Dengan mengacu pada teori ini sehingga mengenai hal ini, solusi yang dapat diberikan adalah bagaimana memperbaiki substansi hukum mengenai fintech dan P2P lending secara komprehensif, kemudian bagi OJK adalah mengeluarkan himbauan bagi platform online di Indonesia dalam menagih penerima pinjaman yang gagal bayar secara tidak baik melalui surat yang dikirim langsung kepada seluruh platform peer to peer lending di Indonesia. Selain adanya code of conduct (pedoman perilaku) yang harus dipatuhi oleh anggota asosiasi, sejauh ini mitigasi cara penagihan yang wajar masih menggunakan kode etik dan tanggung jawab pihak penyelenggara. ${ }^{50}$

\section{CONCLUSION}

Salah satu dampak dari era globalisasi adalah kemajuan teknologi yangmana hal ini kemudian memunculkan kemudahan bagi masyarakat salah satunya untuk melakukan peminjaman uang berbasis teknologi atau yang disebut Financial Technologi, yang salah satu bentuk dari fintech ini adalah peer to peer lending (P2P lending). Keberadaan P2P lending sendiri semakin menjamur terkhusus pada era pandemi virus Covid-19 ini, terkhusus yang bersifat ilegal dengan memaanfaatkan kesulitan ekonomi masyarakat yang terdampak pandemic Covid-19. Namun pada kenyataannya, kerugian yang diakibatkan oleh kehadiran fintech masih kerap dirasakan oleh masyarakat. Untuk saat ini, OJK sebenarnya telah memiliki instrumen hukum untuk mengatur pinjol, bahkan sudah dibentuk Satgas Waspada Investasi yang beranggotakan OJK dan instansi lainnya. Keberadaan Satgas Waspada Investasi sendiri sebenarnya sudah menunjukkan upaya perlindungan hukum terhadap fintech terkhusus yang sifatnya illegal yang dibuktikan dengan adanya pinjol ilegal yang diblokir oleh anggota Satgas Waspada Investasi. Namun selain mekanisme represif seperti pembentukan Satgas Waspada Investasi, maka diperlukan pembaharuan terkait syarat pendirian, perizinan serta mekanisme gagal bayar pada fintech terkhusus P2P lending ini sekaligus sosialisasi kepada masyarakat untuk lebih waspada terhadap keberadaan P2P lending ini.

\section{REFERENCES}

Appadurai, Arjun. "Modernity at Large, Cultural Dimensions of Globalization." Public Worlds Volume 1 (2003).

Barkatulah, Abdul Halim. Hukum Perlindungan Konsumen Kajian Teoretis Dan Perkembangan Pemikiran). Bandung: Nusa Media, 2008.

Darman. "Financial Technology (FinTech): Karakteristik Dan Kualitas Pinjaman Pada Peer

49 Any Ismayawaty, "Pengaruh Budaya Hukum Terhadap Pembangunan Hukum Di Indonesia (Kritik Terhadap Lemahnya Budaya Hukum Di Indonesia)," Pranata Hukum Volume 6 n (2011).

${ }^{50}$ Ibid., 
to Peer Lending Di Indonesia." Jurnal Manajemen Teknologi Vol. 18 No (2019).

Emil Salim, Sri Edi Swasono, Yudo Swasono, Tanri Abeng, Yaumil C. Agoes Achir, Marco

P., and Sumampouw. Manajemen Dalam Era Globalisasi. Jakarta: Elex Media Komputindo, 1997.

Friedmann, Lawrence M. Das Rechtssystem Im Blickfeld Der Sozialwissenschaften. Das Rechtssystem Im Blickefeld Der Sozialwissenschaften, 2020. https://doi.org/10.3790/978-3-428- 449484.

Harahap, M. Yahya. Segi-Segi Hukum Perjanjian. Bandung: Alumni, 1986.

Hasyim, H.A. Dardiri. Hukum Perikatan Dan Perjanjian. Surakarta: Penerbitan dan Percetakan UNS (UNS Press), 2015.

Ilmar, Aminuddin. Hak Menguasai Negara Dalam Privatisasi BUMN. Jakarta: Kencana, 2012. Ismayawaty, Any. "Pengaruh Budaya Hukum Terhadap Pembangunan Hukum Di Indonesia (Kritik Terhadap Lemahnya Budaya Hukum Di Indonesia)." Pranata Hukum Volume 6 n (2011).

Kaelan. Pendidikan Pancasila, Proses Reformasi, UUD Negara Amandemen 2002, Pancasila Sebagai Sistem Filsafat, Pancasila Sebagai Etika Politik, Paradigma Bermasyarakat, Berbangsa Dan Bernegara. Yogyakarta: Paradigma, 2004.

Kharismai, Dona Budi. "Problematika Mekanisme Penyelesaian Pinjaman Gagal Bayar Pada Pinjaman Online Di Indonesia." Jurnal Rechtsvinding 7 April (2020).

Marbun, S. F. Hukum Administrasi Negara I. Yogyakarta: FH UII Press, 2012.

Marilang, M. "IDEOLOGI WELFARE STATE KONSTITUSI: HAK MENGUASAI NEGARA ATAS BARANG TAMBANG.” Jurnal Konstitusi, 2012. https://doi.org/10.31078/jk.

McCoubrey, Hilaire. Nigel D. White. Textbook and Jurisprudence. London: Blackstone Press Limited, 1999.

Meliala, Adrianus. Praktik Bisnis Curang. Jakarta: Pustaka Sinar Harapan, n.d.

Mertokusumo, Soedikno. Mengenal Hukum Suatu Pengantar. Yogyakarta: Liberti, 1986.

Novita, Windy Sonya. "Aspek Hukum Peer to Peer Lending (Identifikasi Permasalahan Hukum Dan Mekanisme Penyelesaian).” Jurnal Privat Law Vol. VIII (2020).

Pardosi, Rodes Ober Adi Guna. "Perlindungan Hak Pengguna Layanan Pinjaman Online." JURNAL HAM Desember 2 (n.d.).

"Peer to Peer Lending (P2P) Pelajaran Dari China." Jurnal LPPI No A.13 Ap (2019).

Priyonggojati, Agus. "Perlindungan Hukum Terhadap Penerima Pinjaman Dalam Penyelenggaraan Financial Technology Berbasis Peer To Peer Lending." Jurnal USM Law Review Vol 2 No 2 (2019).

Purbaya, Angling Adhitya. "Guru Honorer Di Semarang Terjerat Pinjol, Utang Rp 3,7 Juta Bengkak Rp 206 Juta." Detik.Com, 2021. https://news.detik.com/berita-jawatengah/d-5592751/guru-honorer-di-semarang-terjerat-pinjol-utang-rp-37-jutabengkak-rp-206-juta.

Rachmawati. "5 Cerita Mereka Yang Terjerat Pinjaman Online, Ada Yang Bunuh Diri Hingga Merampok Untuk Bayar Utang." Kompas, n.d. https:/ / regional.kompas.com/read/2021/05/20/060700978/5-cerita-mereka-yangterjerat-pinjaman-online-ada- yang-bunuh-diri-hingga?page $=$ all.

Rahardjo, Satjipto. Biarkan Hukum Mengalir. Jakarta: Kompas, 2008.

—. "Hukum Dalam Kerangka Ilmu- Ilmu Sosial Budaya." Majalah Ilmiah Masalah- 
Masalah Hukum nomor 1 ta (1972).

-. Penegakkan Hukum Progresif. Penerbit Buku Kompas, 2010.

Rayyan Sugangga, Dkk. "Perlindungan Hukum Terhadap Pengguna Pinjaman Online (Pinjol) Ilegal." Jurnal Pakuan Justice Journal Of Law Volume 01 (n.d.).

Saksonova, S., Kuzmina, I., \& Merlino. "Fintech as Financial Innovation - the Possibilities and Problems of Implementation." European Studies Journal XX (3A) (2017).

Saputra, Adi Setiadi. "Perlindungan Terhadap Pemberi Pinjaman Selaku Konsumen Dan

Tanggung Jawab Penyelenggara Peer to Peer Lending Dalam Kegiatan Peer to Peer Lending Di Indonesia." Jurnal VeJ Volume $5 \mathrm{~N}$ (n.d.).

Suhartini. Perspektif Global. Yogyakarta: Fakultas Ilmu Komunikasi Universitas Negeri Yogyakarta, 2004.

Suryani, Leony Sondang. "Implikasi Putusan Mahkamah Konstitusi No 22/PUU-XV/2017

Tentang Pengujian UU Perkawinan Mengenai Batas Usia Perkawinan Terhadap

Pemenuhan Dan Perlindungan Hak Anak Perempuan.” Diponegoro, 2019.

Suteki. Desain Hukum Di Ruang Sosial. Yogyakarta: Thafa Media, 2013.

Wahyudi, Slamet Tri. "Problematika Penerapan Pidana Mati Dalam Konteks Penegakan Hukum Di Indonesia." Jurnal Hukum Dan Peradilan Volume 1, (2012). 